\title{
Free and total testosterone levels in field males of Octodon degus (Rodentia, Octodontidae): accuracy of the hormonal regulation of behavior
}

\author{
Niveles de testosterona libre y totales en machos silvestres de Octodon degus (Rodentia, \\ Octodontidae): exactitud de la regulación hormonal del comportamiento
}

MAURICIO SOTO-GAMBOA

Instituto de Zoología, Facultad de Ciencias, Universidad Austral de Chile, Casilla 567, Valdivia, Chile; e-mail:mrsoto@uach.cl

\begin{abstract}
Animals exhibit continuous seasonal changes in physiological, morphological and behavioral traits associated to their natural annual cycles. One of the most important changes in the organism occurs at the initiation of breeding season. In males these changes include activation of spermatogenesis, enhance of sexual secondary characters and an increase of aggressiveness. All of theses changes are basically regulated by testosterone, but the physiological basis of this testosterone regulation and the effective hormone proportion that acts in target tissues are unknown. In this work I evaluated the relationship between total testosterone, free testosterone associated to aggressive behavior in wild males of Octodon degus. I compared hormonal levels and aggressive behavior during pre, middle and post breeding periods. Results showed that behavioral aggressiveness was correlated with both total and free testosterone in June, during the beginning of breeding season, but not at other times. Results also indicated a lack of relationship between free and total testosterone in most of breeding period. I discuss the importance of this behavior-hormonal regulation (determined by free testosterone) and the physiological importance of this mechanism to the organism.
\end{abstract}

Key words: free testosterone, total testosterone, globulin, binding-proteins, aggressive behavior, challenge hypothesis, Octodon degus.

\section{RESUMEN}

Los animales presentan variaciones estacionales continuas que incluyen cambios fisiológicos, morfológicos y conductuales, asociados al ciclo anual. Estos cambios generalmente están activados por factores endógenos o exógenos, pero son regulados por el sistema endocrino de organismo. Uno de los cambios más importantes ocurre en el inicio del periodo reproductivo. Durante este periodo los machos presentan cambios asociados a la producción de espematozoides, exacerbación de caracteres sexuales secundarios y un aumento de la agresividad. Todos estos cambios son regulados en parte por los niveles de testosterona, sin embargo, los mecanismos fisiológicos de esta regulación son desconocidos. En este trabajo evalué la relación que existe entre los niveles de testosterona libre y totales, y examiné su posible asociación con los niveles de agresividad en machos de una población natural de Octodon degus. Mis resultados indicaron que la agresividad se correlaciona directamente con los niveles de testosterona libre y totales solo durante el mes de junio, al inicio del periodo reproductivo, pero no durante el resto del ciclo reproductivo de esta especie. Esto indicaría que la agresividad solo se correlaciona con los niveles de testosterona libre ya que en el medio y el final del periodo reproductivo los niveles de testosterona total se mantienen altos sin que se manifiesten dichas conductas. Finalmente, discuto la importancia de la regulación fina de la conducta determinada por la testosterona libre y la importancia fisiológica de este mecanismo de regulación dentro del organismo.

Palabras clave: testosterona libre, testosterona total, globulinas, proteínas ligando, hipótesis de desafío, Octodon degus.

\section{INTRODUCTION}

Animals exhibit seasonal changes in their physiology, morphology and behavior coupled to natural annual events. These include changes in body reserves, body coloration and sexual maturation associated to breeding events (Dufty et al. 2002, Goymann \& Wingfield 2004). These changes can be activated by endogenous or exogenous factors, but they are regulated by 
the endocrine system of the organism (Nelson 2000, Deviche et al. 2001, Dufty et al. 2002). By example, glucocorticoids change seasonally in association with environmental stress, food and/or water availability (Wingfield et al. 1998, Romero et al. 2000, Sapolsky et al. 2000, Romero 2002, Goymann \& Wingfield 2004, Wingfield 2004), whereas androgens and estrogens increase during the reproductive period in males and females (Wingfield et al. 1994, Ulibarri \& Yahr 1996, Faulkes \& Abbott 1997, Sinervo et al. 2000, Buck \& Barnes 2003, Wingfield \& Sapolski 2003). In this study I analyze the importance of hormonal regulation, particularly testosterone regulation, on the aggressive behavior in males seasonally.

Among vertebrates, testosterone has several physiological functions on the organism. It regulates spermatogenesis and development of secondary sexual characters, and participates in the activation and regulation of sexual male behavior (Wingfield et al. 1997, Nelson 2000, Blottner et al. 2000). In this context, testosterone levels have direct effects in mating activities including females' attractiveness to males, and on male-male interactions for the access to females (Wingfield et al. 1990, Wingfield et al. 1994, Emerson 1997, Cavigelli \& Pareira 2000, Sinervo et al. 2000, Goodson $\&$ Bass 2001, Dunlap et al. 2002). In addition, testosterone secretion can be activated by social stimuli during the breeding season (Wingfield et al. 1992, Wingfield et al. 1997, Cavigelli \& Pareira 2000, Soto-Gamboa et al. 2005). In rodents, testosterone levels have been associated to territory defense, reproductive group formation, and social dominance (Zielinski \& Vandenbergh 1993, Wolff 1994, Faulkes \& Abbott 1997, Clarke \& Faulkes 1998, Cavigelli \& Pareira 2000, Rogovin et al. 2003). Nevertheless, not all rodent species exhibit a direct relationship between testosterone concentration and aggressiveness. The aggressive behavior of several Myomorhp species of Peromyscus and Phodopus exhibit no direct relationship to testosterone levels. In these cases, aggressiveness seems more linked to vasopressin levels (Bester-Meredith et al. 1999, Jasnow et al. 2000, Goodson \& Bass 2001).

This apparent lack of association among testosterone concentration and aggressive behavior can be the consequence of three physiological pathways. First, hormone actionreceptor pathway, where the number of receptors in the targets nuclei cell is low and continuously saturated (Tramonti et al. 2003). Second, receptors may have low affinity to testosterone; and third, testosterone might be associated with binding proteins (Hadley 1992). The hormone action-receptor pathway has been described in birds where the number of testosterone receptors in song nuclei cells of brain change seasonally, decreasing from the mid breeding season (Wingfield et al. 1997, Tramonti et al. 2003, Moore et al. 2004). A low affinity of receptors has been described in genetically manipulated mice, in which mutant receptor genes have low testosterone affinity and males mutants act (physiologically and behaviorally) as females (Yeh et al. 2002). Finally, most plasma testosterone in mammals can be bound to albumin, specifically to sex hormone-binding globulins (SHBG), whereas a smaller fraction remains unbound (Vermeulen et al. 1999). This remaining testosterone is the fraction available at cellular level to activate target tissues, and is recognized as free testosterone (Wingfield et al. 1990, Hadley 1992, Vermeulen et al. 1999). Therefore, albumins may inhibit or regulate the testosterone effects over target tissues.

The relationship between free and total testosterone has been well studied in humans for diagnostic purposes (more detail in Rosner 1990, Vermeulen et al. 1999, Hampl et al. 2001), but rarely so in natural populations of mammals. Therefore, the objectives of this work were to determine the relationship between male's behavioral aggression and testosterone levels in a wild population of the rodent Octodon degus (Molina, 1782), and examine if total testosterone is an adequate measure of hormone levels affecting target tissues. To evaluate these objectives, I studied variations in hormonal levels and behavior of wild animals during their breeding cycle.

\section{MATERIAL AND METHODS}

I studied a natural population of $O$. degus in

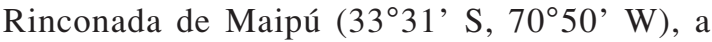
field station of the Universidad de Chile, located near Santiago, in central Chile. Observations were conducted during April to 
September 2002 and 2003, encompassing the reproductive cycle of degus: pre-breeding (Abril-May), breeding (June-July), and postbreeding (August-September) periods (Bustos et al. 1977, Contreras \& Bustos-Obregón 1977, Ebensperger \& Hurtado 2005). I captured animals using a capture effort of 100 Sherman live traps during five days every month. All captured animals were sexed, weighed and marked with a unique plastic colored collar. For later hormonal analysis (see below), I took blood samples from all captured males (approximately $700 \mu \mathrm{L}$ from the suborbital sinus with a heparinzed glass pipette), following the methodology described by Kenagy et al (1999). To avoid manipulation effects, traps were checked every $30 \mathrm{~min}$, following Place et al. (2000). Preliminary data also reveled that degus do not show significant variation in testosterone and glucocorticoid levels when animals are kept between 0 to $2 \mathrm{~h}$ inside traps (KS. Matt \& F. Bozinovic, unpublished results). The handling time during the acquisition of samples never exceeded $30 \mathrm{sec}$, and samples were obtained immediately after animals were removed from the traps.

Five days after capture, I recorded behavioral data through direct observations, consisting in $15 \mathrm{~min}$ of focused male observation, during which I registered all interactions between the focused and other animals (Altmann 1974, Martin \& Bateson 1993). In total, between 10 and 30 focal observations per month were registered depending on the season. Interactions were classified using four different classes based on the behavioral repertory described by Fulk (1976). I focused my analysis onto agonistic interactions, including chases, mounting and foreleg pushing, and registering the winner or loser male based on their capacity to remain or abandon the conflicted area. I used these data to calculate the Dominance Index (DI) as:

$$
\mathrm{DI}=(\mathrm{Wc}-\mathrm{Lc}) / \mathrm{Tc},
$$

where $\mathrm{Wc}$ represents the number of individual winner confrontations, Lc represents the looser confrontations, and Tc represents total of agonistic interactions. DI negative values indicate that males lose in the majority of agonistic interactions, DI near cero represent males with si- milar looser and winner interactions, while positive DI values represent males with mostly victorious confrontations.

Blood samples were transported to the laboratory in a refrigerated cooler to be centrigugated at 7,000 $\mathrm{rpm}$ for $10 \mathrm{~min}$ within the next eight hours of being taken. Plasma was separated from cells and stored at $-20{ }^{\circ} \mathrm{C}$ for subsequent hormone assays. Testosterone concentration was measured by enzyme immunoassay with reagents supplied by the World Health Organization program for the Provision of Matched Reagents for RIA of Hormone in Reproductive Physiology, and following recommended procedures (Sufi et al. 1998). For testosterone determination, I extracted the hormone by diethil-ether, evaporating $50 \mu \mathrm{L}$ of plasma, and resuspending in RIA assay buffer. This method had resolution limits for testosterone of $0.12 \mathrm{ng}$ $\mathrm{mL}^{-1}$. All samples were analyzed in duplicated. Assay precision estimated from the coefficient of variation was $5.3 \%$ for intra-assay whereas precision assessed from the inter-assay was 9.3 $\%$. Free testosterone was determined with CoatA-Cont ${ }^{\circledR}$ Kit of hormone determination, followed by a $\mathrm{I}^{125}$ radioinmunoassay procedure. Intra-assay coefficient of variation was $15 \%$, whereas the inter-assay reached $19 \%$.

Statistical analyses were performed using parametric and non-parametric statistics. To analyze behavioral relationships, I used the total number of agonistic interactions. I utilized the Kruskal-Wallis test to evaluate significant differences across months. Monthly variation of free and total testosterone was analyzed using the Kruskal-Wallis test. The relationship between total and free testosterone was examined monthly through Linear Regression Analysis. Finally, Spearman Correlation Analysis was used to determine the relationship between dominance index and total and free testosterone (Zar1996). All statistical analyses were performed using Statistica 6.0 software (StatSoft 2001). Results are presented as means \pm standard error (SE).

All experimental procedures were carried out according to the current Chilean law, permit number SAG-698 by the Servicio Agrícola y Ganadero, Ministerio de Agricultura, and under the approval of the Pontificia Universidad Católica de Chile Ethical Committee. 


\section{RESULTS}

Wild degu males exhibited a clear seasonal aggression pattern (Fig. 1A). During the prebreeding period (April-May), animals showed low levels of aggression among males, but this pattern changed significantly during June where aggression peaked $\left(\mathrm{H}_{5}=53.94, \mathrm{P}<\right.$ $0.0001)$. During the successive months, relatively lower levels of agonistic interactions occurred (Fig. 1A). This pattern was mirrored by total testosterone (Fig. 1B). Males presented the highest level of total testosterone during June $\left(\mathrm{H}_{5}=30.15, \mathrm{P}<0.0001\right)$, and these levels remained similarly high through July and August (Fig. 1B). In contrast, free testosterone exhibited a significantly high peak during June only $\left(\mathrm{H}_{5}=34.34, \mathrm{P}<0.0001\right)$, remaining at minimum levels both before and after this peak (Fig. 1C).

The linear regression analysis showed that total and free testosterone were significantly associated during June only $\left(\mathrm{R}^{2}=0.482, \mathrm{P}=\right.$ 0.001, Fig. 2). In pre-breeding period I did not find significant relations (April: $\mathrm{R}^{2}=0.044, \mathrm{P}$ $=0.49$; May: $\mathrm{R}^{2}=0.07, \mathrm{P}=0.29$ ), similar to meddle and final breeding season (July: $\mathrm{R}^{2}=$ $0.17, \mathrm{P}=0.36$; August: $\mathrm{R}^{2}=0.06, \mathrm{P}=0.60$; September: $\left.\mathrm{R}^{2}=0.25, \mathrm{P}=0.740\right)$. As expected both total and free testosterone levels were positively associated with the rate of aggression and (DI) (Fig. 3). Thus, individuals with elevated levels of testosterone during June exhibited a high frequency of aggressive interactions and were more dominant.

\section{DISCUSSION}

Seasonal changes in aggressive behavior linked to major breeding events are common in wild mammals (King 1973, Poole \& Morgan 1975, Schaffner \& French 1997, Côté 2000). Previous studies suggested that degu breeding is initiated during late May and is characterized by social instability with continuous agonistic challenge among males (Fulk 1976, Solís \& Rosenmann 1990, Veloso 1997). This study demonstrated a clear association between aggressive behavior and main events of breeding period where social instability is restricted to the beginning of this period (in June), and associated with a quick social structure formation. Males
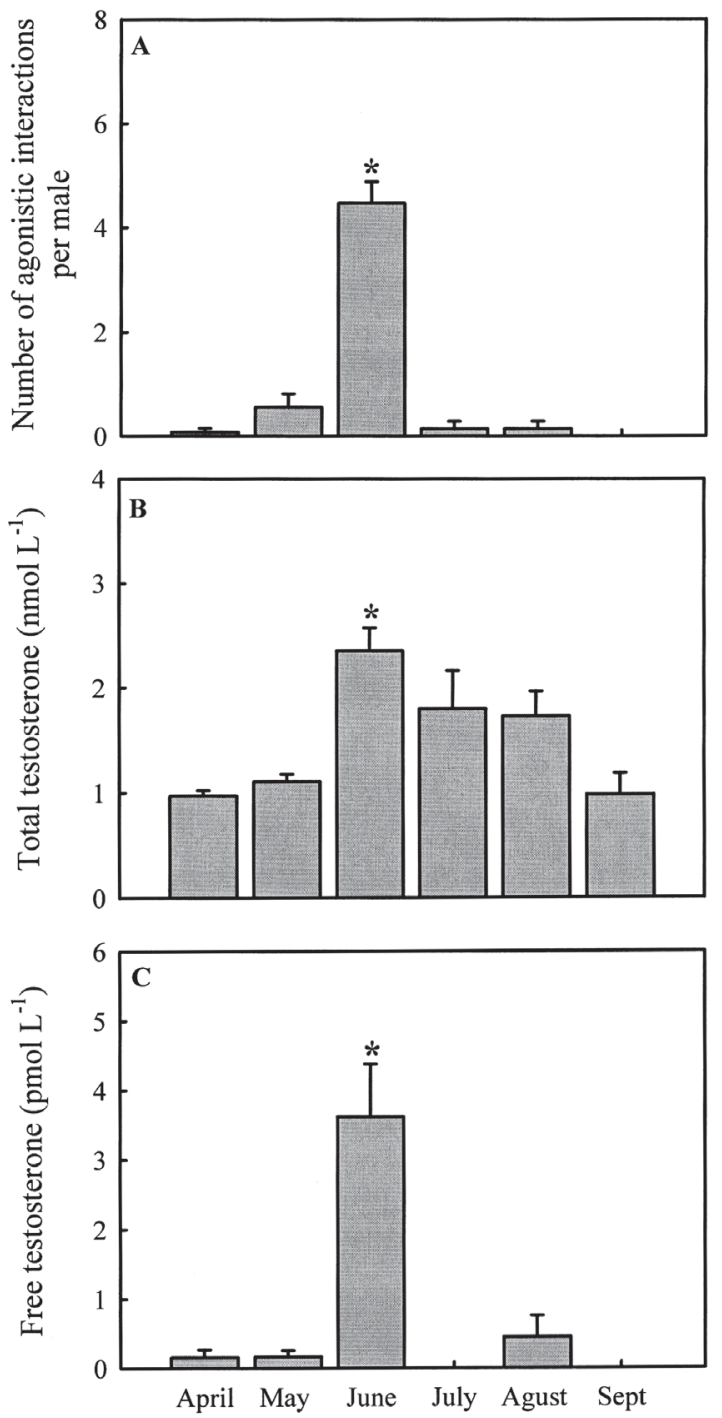

Fig. 1: Monthly changes on the aggressive behavior and hormonal concentration in males of Octodon degus. Panel A exhibit months variation of agonistic interactions per male, B present total testosterone levels variations, and $\mathrm{C}$ represent seasonal variation of free testosterone levels. An asterisk (*) indicates significant differences at $\mathrm{P}<0.05$ using the Kruskal-Wallis test. Sample size was $\mathrm{n}=13$ for April, $\mathrm{n}=18$ for May, $n=19$ for June, $n=7$ for July, $n=7$ for August, and $n=6$ for September.

Variaciones mensuales en el comportamiento agresivo y concentraciones hormonales en machos de $O$. degus. En el gráfico A se presentan las variaciones en el número de interacciones agonistas por machos en los diferentes meses del estudio, B se presentan las variaciones mensuales de los niveles de testosterona totales, y en $\mathrm{C}$ se presentan las variaciones estacionales de los niveles de testosterona libre. El asterisco (*) representa valores de significancia con un $\mathrm{P}<0,05$ utilizando una prueba de Kruskal-Wallis. Los tamaños muestréales fueron $\mathrm{n}=13$ para abril, $\mathrm{n}=18$ para mayo, $\mathrm{n}=19$ para junio, $\mathrm{n}$ $=7$ para julio, $n=7$ para agosto, $y \mathrm{n}=6$ para septiembre. 


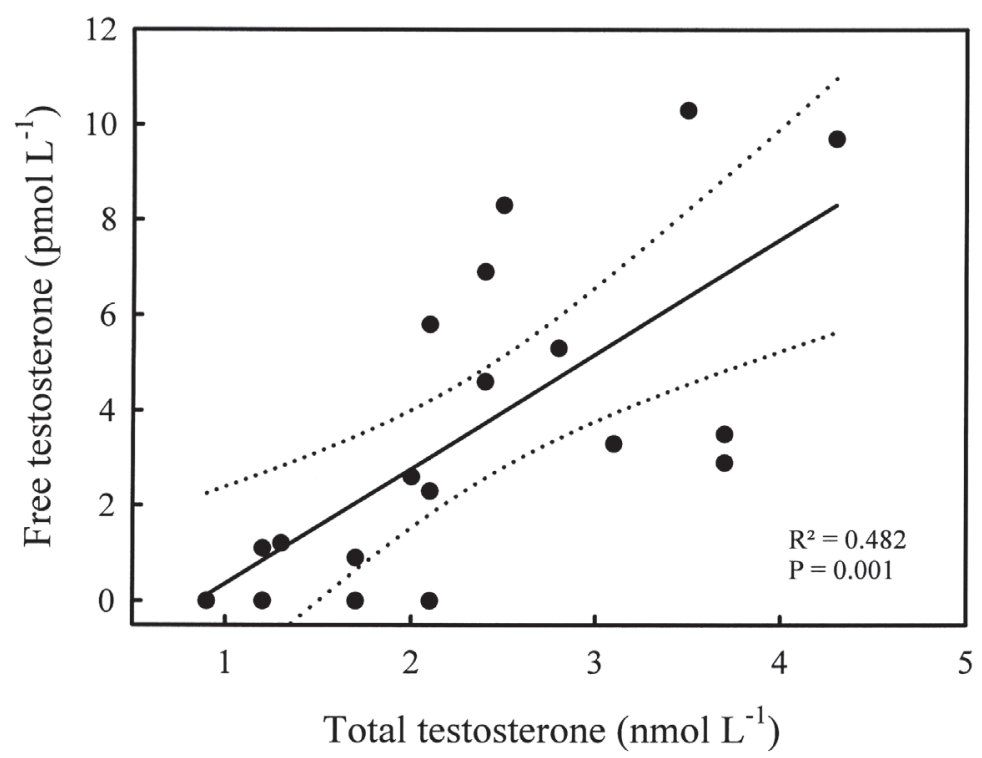

Fig. 2: Relationship between free and total levels of testosterone during June. Free and total testosterone presents a linear relationship during this period. Linear regression analysis show a significant relation with $\mathrm{R}^{2}=0.482$. Dotted lines represent the $95 \%$ of confidence of data, with $\mathrm{n}=$ 19 males.

Relación entre los niveles de testosterona libre y total durante el mes de junio. La testosterona libre presenta una relación linear con la testosterona total. El análisis de regresión lineal muestra una relación significativa, con un $\mathrm{R}^{2}=0,482$. Las líneas discontinuas representan el $95 \%$ de intervalo de confianza y con un $\mathrm{n}=19$ machos.

establish territories and monopolize females at this time resulting in harem formation (Fulk 1976, Ebensperger et al. 2004, Soto-Gamboa 2004). Once territories are established, agonistic interactions among males decline significantly (July to September, Fig. 1A), most likely due to a displacement of transient males that were unable to acquire a territory (SotoGamboa et al. 2005). Similar results were reported for laboratory degus indicating that male-male aversion increases during breeding season (Solís \& Rosenmann 1990).

Seasonal changes in free and total testosterone levels closely followed behavioral changes. Both free and total testosterone concentration reached their highest levels during June, but only total testosterone maintained these high levels during late breeding months (July and August). During June, free and total testosterone levels were highly and positively correlated indicating that at this time, total testosterone is a good predictor of hormone reading target tissues. A lack of relationship between both testosterone forms during middle and final phases of reproductive season probably indicates a fine regulation on free testosterone levels through the action of androgen globulin-binding proteins (Ekins 1990, Klukowski et al. 1997, Titus et al. 1997).

The guinea pig (Cavia porcellus) is one of the most studied caviomorph rodents. In this species, the concentration of total testosterone in captive individuals prior to male-male confrontations test is not a good predictor of male dominance (Sachser \& Lifjeld 1989). Nevertheless, in multi-males groups testosterone is positively correlated with dominance primarily during times of social instability, but not so during posterior social stability (Sachser \& Prove 1986, Hennessy 1999). These results have been associated to alternative mating strategies where at low densities these animals tend to be monogamous or polygamous (harems), but change to promiscuity at high densities (Asher et al. 2004). Degus showed a similar pattern where total testosterone concentrations plays an important role during social instability, but this relationship breaks down when social interactions diminish. 

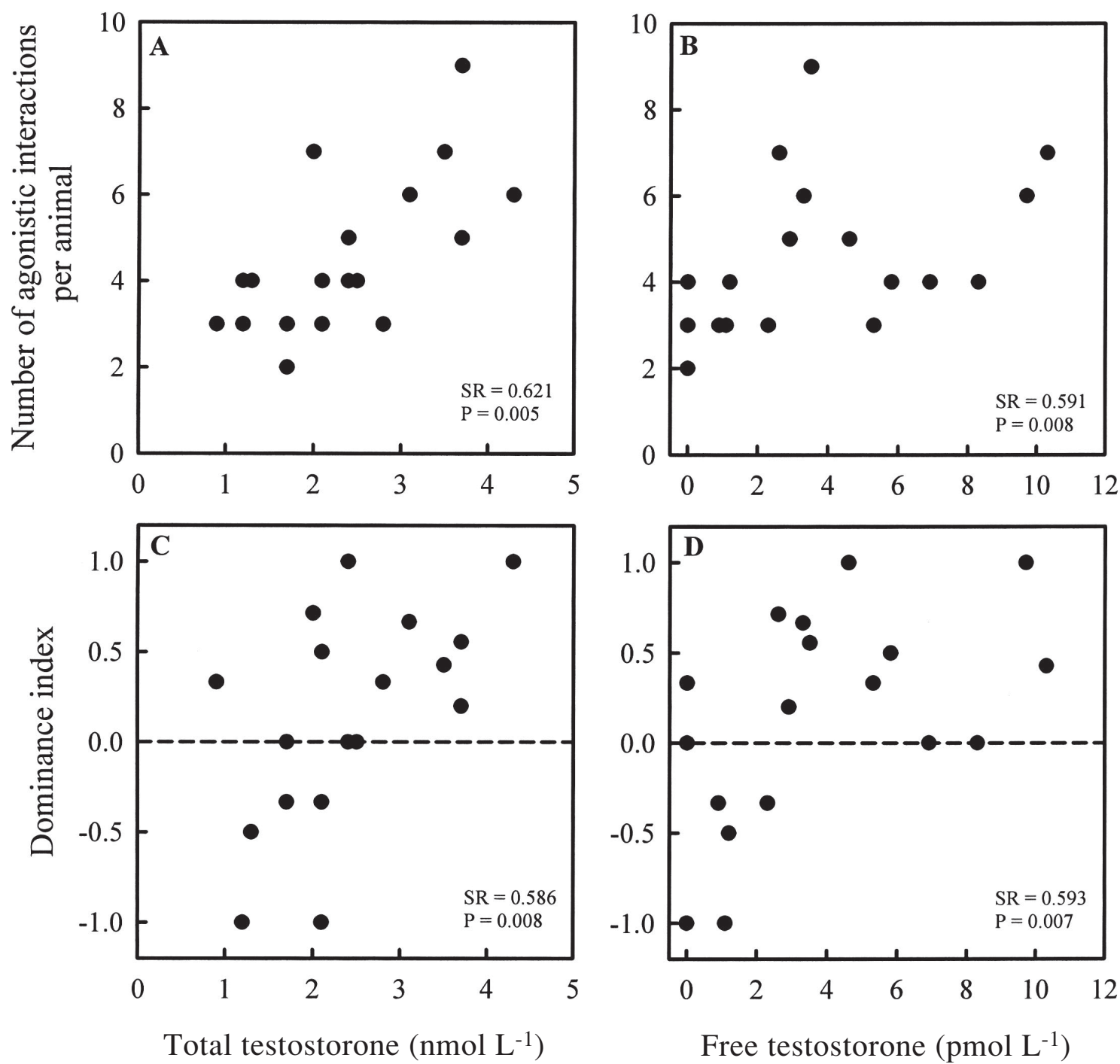

Fig. 3: Relationship between aggressive behavioral traits and testosterone levels during June. Panels A and B represent the positive relationship between aggressive traits, measured as total agonistic interactions per male with total and free testosterone levels respectively. Panels C and D represent Dominance index relationship with total and free testosterone levels respectively. In all cases Spearman correlation are significant at $\mathrm{P}<0.05$ using $\mathrm{n}=19$ males.

Relación entre los rasgos de comportamiento agresivo y los niveles de testosterona determinados durante el mes de junio. En los gráficos A y B se presenta la relación positiva que existe entre la tasa de interacciones agonista por macho y los niveles de testosterona totales y libres respectivamente. En los gráficos C y D se presenta la relación entre el Índice de Dominancia y los niveles de testosterona total y libre, respectivamente. En todos los casos, las correlaciones de Spearman fueron significativas con un $\mathrm{P}<0,05$ utilizando un $\mathrm{n}=19$ machos.

However, degus have a stereotyped mating system consisting in one territorial male with one to three females (Fulk 1976, Ebensperger et al. 2004, Soto-Gamboa 2004, Soto-Gamboa et al. 2005). This could be indicating that total testosterone is associated to behavioral interactions between males and playing an important role during harem formation.
These results indicate that aggressive behavior among males is more associated to free testosterone than total testosterone levels. But, does free testosterone regulate aggressive behavior, or does a lack of aggressive interactions activate androgen globulin-binding protein secretion? Winfield et al. (1990) proposed the 'challenge hypothesis' according 
to which testosterone levels are directly associated with social interactions. Thus the intensity of males' interactions enhances testosterone secretion and, as a consequence, increases male hormonal levels enhancing males' aggressiveness (Wingfield et al. 1990, Cavigelli \& Pareira 2000, Ostner \& Kappeler 2002, Muller \& Wrangham 2004). Degu males exhibiting high agonistic interactions also showed high values of dominance, indicating a high frequency of social interactions, and consistently high levels of free testosterone. Thus, social stimuli may activate testosterone secretion. During June (begin reproductive season), free testosterone is directly associated with total testosterone, indicating low concentrations of globulin-binding proteins. As soon as the territories have been established and social stimuli diminish, levels of free testosterone could be modulated by an increase of globulin-binding protein concentration, disabling testosterone actions over target cells. Therefore, the remaining testosterone can be gradually degraded through the action of aromatase (producing 17 $\beta$-estradiol), or reduced to $5 \beta$-dehidrotestosterne (Wingfield et al. 1997, Soma et al. 1999, Nelson 2000, SotoGamboa 2003). A similar physiological pathway has been proposed using methodological procedures based on hormonal implants. In these cases, no relationship has been described between agonistic behavior and artificially enhanced testosterone levels during mid and late breeding seasons (Klukowski et al. 1997, Klukowski \& Nelson 1998, BesterMeredith et al. 1999, Jasnow et al. 2000, Goodson \& Bass 2001).

Hormones have pleiotrophic effects over morphological and physiological traits, and could affect individual performance (Ketterson et al. 1996, Wingfield et al. 1997, Ketterson \& Nolan 1999, Dufty et al. 2002, Ketterson et al. 2004). Since these multiples effects have potentially associated benefits and costs, an efficient regulation is fundamental. High levels of testosterone increase field metabolic rate and decrease of body weight (Place et al. 2002), and suppress immune systems (Wedekind \& Folstad 1994, Wingfield et al. 1997, Klein \& Nelson 1998, Westneat et al. 2003, Peters et al. 2004). Therefore, restricting the action of testosterone over target tissues to the required time periods only could reduce these by- product physiological costs. Captive male degus increase daily metabolic rate during breeding season independently of social interactions, indicating an augment of costs associated to gonadal activation and testosterone production (Solís \& Rosenmann 1990). Therefore, a fine regulation of free testosterone during social stability could reduce costs of high testosterone levels needed during harems formation.

Finally, this study is the first to report estimates of free testosterone to a field mammal. The importance of the steroidal hormone transport on blood exist, particularly regarding androgens is a major unknown (Ekins 1990). A lack of relation between seasonal change of free and total testosterone levels throughout most of breeding events in degus indicates that total testosterone measures are not adequate to evaluate hormonal regulation of behavior. Nevertheless, two caveats are important. First, low concentrations of free testosterone, nearby to detection limits, could affect the relationship between free and total testosterone, specially when not in social instability (most of free testosterone levels were not detectable by the kit). Second, precise age (unknown in this study) may covariate with hormonal levels to influence dominance and performance of males. Young males present high levels of testosterone during puberty and could have posterior consequences during breeding season, three months after (SotoGamboa 2004). Previous laboratory data indicate that mean total testosterone is $2.51 \pm$ $0.29 \mathrm{nmol} \mathrm{L}^{-1}$ for two year's old reproductive males (Bustos-Obregón \& Ramírez 1997) is similar to measures obtained in this study in June $\left(2.35 \pm 0.22 \mathrm{nmol} \mathrm{L} \mathrm{L}^{-1}\right)$, indicating that wild animals most likely were reproductively active but remember unknown if circulating testosterone binding-globulins change with the age, independently of total testosterone.

\section{ACKNOWLEDGEMENTS}

I am grateful to Francisco Bozinovic for the possibility to incorporate this manuscript in to this special volume of the RCHN. Special thanks to Manuel Villalón to facilitate the RIA laboratory to complete hormonal determinations. Thanks to the Universidad de 
Chile and José Daniel Garcia for the access to the study area. This research was funded by a CONICYT Doctoral Thesis Fellowship to MSG, and by FONDAP grants 1501-001, program 1 to $\mathrm{F}$. Bozinovic. This paper is dedicated to the memory of Dr. Mario Rosenmann, my master in the field of Physiological Zoology.

\section{LITERATURE CITED}

ALTMANN J (1974) Observational study of behaviour: sampling methods. Behaviour 49: 227-267.

ASHER M, ES DE OLIVEIRA \& N SACHSER (2004) Social system and spatial organization of wild guinea pigs (Cavia aperea) in natural low density population. Journal of Mammalogy 85: 788-796

BESTER-MEREDITH JK, LJ YOUNG \& CA MARLER (1999) Species differences in paternal behavior and aggression in Peromyscus and their associations with vasopressin immunoreactivity and receptors. Hormones and Behavior 36: 25-38.

BLOTTNER S, M ROHLEDER, O ZINKE \& IW STUERMER (2000) Higher testicular activity in laboratory gerbils compared to wild Mongolian gerbils (Meriones unguiculatus). Journal of Zoology, London 250: 461-466.

BUCK CL \& BM BARNES (2003) Androgen in freeliving arctic ground squirrels: seasonal changes and influence of staged male-male aggressive encounters. Hormones and Behavior 43: 318-326.

BUSTOS E, J IPINZA \& A SPOTORNO (1977) Biología del Octodon degus. Medio Ambiente (Chile) 3: 70-73.

BUSTOS-OBREGÓN E \& O RAMÍREZ (1997) Ageing and testicular function in Octodon degus. Andrologia 29: 319-326.

CAVIGELLI S \& M PAREIRA (2000) Mating season aggression and fecal testosterone levels in male ring-tailed lemurs (Lemur catta). Hormones and Behavior 37: 246-255.

CLARKE FM \& CG FAULKES (1998) Hormonal and behavioral correlates of male dominance and reproductive status in captive colonies of the naked mole-rat, Heterocephalus glaber. Proceedings of the Royal Society of London B 265: 1391-1399.

CONTRERAS L \& E BUSTOS-OBREGÓN (1977) Ciclo reproductivo anual en Octodon degus (Molina) macho. Medio Ambiente (Chile) 3: 83-90.

CÔTÉ SD (2000) Dominance hierarchies in female mountain goats: stability, aggressiveness and determinants of rank. Behaviour 137: 1541-1566.

DEVICHE P, C BREUNER \& M ORCHINIK (2001) Testosterone, corticosterone, and photoperiod interact to regulate plasma level of binding globulin and free steroid hormone in dark-eyed juncos, Junco hyemalis. General Comparative Endocrinology 122: 67-77.

DUFTY AMJ, J CLOBERT \& AP MOLLER (2002) Hormones, developmental plasticity and adaptation. Trends in Ecology and Evolution 17: 190-196.

DUNLAP KD, PL PELCZAR \& R KNAPP (2002) Social interactions and cortisol treatment increase the production of aggressive electrocommunication signals in male electric fish, Apteronotus leptorhynchus. Hormones and Behavior 42: $97-$ 108.
EBENSPERGER LA \& MJ HURTADO (2005) Seasonal changes in the time budget of degus, Octodon degus. Behaviour 142: 91-112.

EBENSPERGER LA, MJ HURTADO, M SOTOGAMBOA, EA LACEY \& AT CHANG (2004) Communal nesting and kinship in degus (Octodon degus). Naturwissenschaften 91: 391-395.

EKINS R (1990) Measurement of free hormones in blood. Endocrinology Reviews 11: 5-46.

EMERSON SB (1997) Testis size variation in frogs: testing the alternatives. Behavioral Ecology and Sociobiology 41: 227-235.

FAULKES CG \& DH ABBOTT (1997) The physiology of a reproductive dictatorship: regulation of male and female reproduction by a single breeding female in colonies of naked mole-rats. In: Solomon NG \& JA French (eds) Cooperative breeding in mammals: 302-334. Cambridge University Press, Cambridge, New York, USA.

FULK GW (1976) Notes on the activity, reproduction, and social behavior of Octodon degus. Journal of Mammalogy 57: 495-505.

GOODSON JL \& AH BASS (2001) Social behavior fuctions and related anatomical characteristics of vasotocin/vasopressin systems in vertebrates. Brain Research Reviews 35: 246-265.

GOYMANN W \& JC WINGFIELD (2004) Allostatic load, social status and stress hormones: the costs of social status matter. Animal Behaviour 67: 591-602.

HADLEY ME (ed) (1992) Endocrinology. Third edition, Prentice Hall Inc., Princeton University Press, Princeton, New Jersey, USA. 608pp.

HAMPL R, M SNAJDEROVA, J LABL, L LISA, M DVORACOVA, M HILL, J SULCOVA \& L STARKA (2001) Sex hormone-binding globulins as a marker of the effect of hormonal treatment in Turner's syndrome. Endocrine Regulations 35: 1724.

HENNESSY MB (1999) Social Influences on endocrine activity in guinea pigs, with comparisons to findings in nonhuman primates. Neuroscience and Biobehavioral Reviews 23: 687-698.

JASNOW AM, KL HUHMAN, TJ BARTNESS \& GE DEMAS (2000) Short-day increases in aggression are inversely related to circulating testosterone concentrations in male Siberian hamsters (Phodopus sungorus). Hormones and Behavior 38: 102-110.

KENAGY GJ, NJ PLACE \& C VELOSO (1999) Relation of glucocorticoids and testosterone to the annual cycle of free-living degus in semiarid central Chile. General and Comparative Endocrinology 115: 236-243.

KETTERSON ED \& VJ NOLAN (1999) Adaptation, exaptation, and constraint: a hormonal perspective. American Naturalist 154: s4-s25.

KETTERSON ED, VJR NOLAN, JM CASTO, CA BUERKLE, E CLOTFELTER, JL GRINDSTAFF, KJ JONES, JL LIPAR, FMA MCNAABB, DL NEUDORF, I PARKER-RENGA \& SJ SCHOECH (2004) Testosterone, phenotype and fitness: a research program in evolutionary behavioral endocrinology. In: Dawson A \& CM Chaturvedi (eds) Avian endocrinology: 19-40. Narosa Publishing House, New Delhi, India.

KETTERSON ED, VJ NOLAN, MJ CAWTHORN, PG PARKER \& C ZIEGENFUS (1996) Phenotypic engineering: using hormones to explore the mechanistic and functional bases of phenotypic variation in nature. Ibis $138: 70-86$.

KING JA (1973) The ecology of aggression behavior. Annual Review of Ecology and Systematics 4: 117138. 
KLEIN SL \& RJ NELSON (1998) Adaptive immune responses are linked to the mating system of arvicoline rodents. American Naturalist 151: 59-67.

KLUKOWSKI LA, JM CAWTHORN \& ED KETTERSON (1997) Effects of experimentally elevated testosterone on plasma corticosterone and corticosteroid-binding globulin in dark-eyed juncos (Junco hyemalis). General and Comparative Endocrinology 108: 141-151.

KLUKOWSKI M \& CE NELSON (1998) The challenge hypothesis and seasonal changes in aggression and steroids in male northern fence lizards (Sceloporus undulatus hyacinthinus). Hormones and Behavior 33: 197-204.

MARTIN P \& P BATESON (1993) (ed) Measuring behaviour, an introductory guide. Second edition, Cambridge University Press, Cambridge, Great Britain. $222 \mathrm{pp}$

MOORE IT, JC WINGFIELD \& EA BRENOWITZ (2004) Plasticity of the avian song control system in response to localized environmental cues in an equatorial songbird. Journal of Neuroscience 10: 10182-10185.

MULLER MN \& RW WRANGHAM (2004) Dominance, aggression and testosterone in wild chimpanzees: a test of the 'challenge hypothesis'. Animal Behaviour 67: 113-123.

NELSON RJ (ed) (2000) An introduction to behavioral endocrinology. Second edition. Sinauer Associates Inc., Sunderland, Massachusetts, USA. 724 pp.

OSTNER J \& PM KAPPELER (2002) Seasonal variation and social correlates of androgen excretion in male redfronted lemurs (Eulemur fulvus rufus). Behavioral Ecology and Sociobiology 52: 485-495.

PETERS A, K DELHEY, AG DENK \& B KEMPENAERS (2004) Trade-offs between immune investment and sexual signalling in male mallards. American Naturalist 164: 51-59.

PLACE NJ, C VELOSO, GH VISSER \& GJ KENAGY (2002) Energy expenditure and testosterone in freeliving male yellow-pine chipmunks. Journal of Experimental Zoology 292: 460-467.

POOLE TB \& HDR MORGAN (1975) Aggressive behaviour of male mice (Mus musculus) towards familiar and unfamiliar opponents. Animal Behaviour 23: 470-479.

ROGOVIN K, JA RANDALL, I KOLOSOVA \& M MOSHKIN (2003) Social correlates of stress in adult males of the great gerbil, Rhombomys opimus, in years of high and low population densities. Hormones and Behavior 43: 132-139.

ROMERO LM (2002) Seasonal changes in plasma glucocorticoid concentrations in free-living vertebrates. General Comparative Endocrinology 128: $1-24$

ROMERO LM, JM REED \& JC WINGFIELD (2000) Effects of weather on corticosterone responses in wild free-living passerine birds. General Comparative Endocrinology 118: 113-122.

ROSNER W (1990) The functions of corticosteroidbinding globulin and sex hormone- binding globulin: recent advances. Endocrinology Reviews 11: 80-91.

SACHSER N \& JT LIFJELD (1989) Social stress in guinea pigs. Physiology and Behavior 46: 137-144.

SACHSER N \& E PROVE (1986) Social status and plasma-testosterone-titters in males guinea pigs (Cavia porcellus). Ethology 71: 103-114.

SAPOLSKY RM, LM ROMERO \& AU MUNK (2000) How do glucocorticoids influence stress responses? Integrating permissive, suppressive, stimulatory, and preparative actions. Endocrinology Reviews 21: 55-89.

SCHAFFNER CM \& JA FRENCH (1997) Group size aggression: 'recruitment incentives' in a cooperatively breeding primate. Animal Behaviour 54: $171-180$

SINERVO B, DB MILES, WA FRANKINO, M KLUKOWSKI \& DF DENARDO (2000) Testosterone, endurance, and Darwinian fitness: natural selection and sexual selection on the physiological bases of alternative male behaviors in side-blotched lizards. Hormones and Behavior 38: 222-233.

SOLÍS R \& M ROSENMANN (1990) Seasonal changes in intermale interactions and metabolism of Octodon degus. In: Gutiérrez O (ed) Comparative psychology of aggression: 51-64. Professor World Peace Academy Press, Santiago, Chile.

SOMA KK, K SULLIVAN \& JC WINGFIELD (1999) Combined aromatase inhibitor and antiandrogen treatment decrease territorial aggression in a world songbird during the nonbreeding season. General and Comparative Endocrinology 115: 422-453.

SOTO-GAMBOA M (2003) Endocrinología y ecología conductual: mecanismos proximales que explican patrones conductuales. In: Bozinovic F (eds) Fisiología ecológica y evolutiva: 443-460. Ediciones Universidad Católica de Chile, Santiago, Chile.

SOTO-GAMBOA M (2004) Formación y estabilidad de estructuras sociales en micromamíferos, su regulación hormonal y la importancia de las interacciones entre machos. Tesis de Doctorado, Facultad de Ciencias Biológicas, Pontificia Universidad Católica de Chile, Santiago, Chile. iv + 133.

SOTO-GAMBOA M, M VILLALÓN \& F BOZINOVIC (2005) Social cues and hormone levels in male Octodon degus (Rodentia): a field test of the challenge hypothesis. Hormones and Behavior 47: 311-318.

STATSOFT (2001) STATISTICA (data analysis software system). Version 6. http://www.statsoft.com. Tulsa, Oklahoma, USA.

SUFI S, A DONALDSON \& S JEFFCOATE (1998) Who matched reagent, programme steroid radioimmunoassay method manual. United Nations Organization, London, United Kingdom. 65 pp.

TITUS RC, ED KETTERSON \& VJ NOLAN (1997) High testosterone prior to song crystallization inhibits singing behavior in captive yearling dark-eyed juncos (Junco hyemalis). Hormones and Behavior 32: $133-140$.

TRAMONTI AD, JC WINGFIELD \& EA BRENOWITZ (2003) Androgens and estrogens induce seasonallike growth of song nuclei in the adult songbird brain. Journal of Neurobiology 57: 130-140.

ULIBARRI C \& P YAHR (1996) Effects of androgens and estrogens on sexual differentiation of sex behavior, scent marking, and the sexually dimorphic area of the gerbil hypothalamus. Hormones and Behavior 30: $107-130$.

VELOSO C (1997) Energética reproductiva del roedor precocial hervíboro Octodon degus (rodentia: Octodontidae). Tesis de Doctorado, Facultad de Ciencias, Universidad de Chile, Santiago, Chile. xxi $+165$

VERMEULEN A, L VERDONCK \& JM KAUFMAN (1999) A critical evaluation of simple methods for the estimation of free testosterone in serum. Journal of Clinical Endocrinology \& Metabolism 84: 36663672 . 
WEDEKIND C \& I FOLSTAD (1994) Adaptative and nonadaptative immunosuppression by sex hormones? American Naturalist 143: 936-938

WESTNEAT DF, D HASSELQUIST \& JC WINGFIELD (2003) Tests of association between the humoral immune response of red-winged blackbirds (Agelaius phoeniceus) and male plumage, testosterone, or reproductive success. Behavioral Ecology and Sociobiology 53: 315-323.

WINGFIELD JC (2004) Control of behavioral strategies for capricious environments. Animal Behaviour 66: 807-816.

WINGFIELD JC, RE HEGNER, AMJR DUFTY \& GF BALL (1990) The "challenge hypothesis": theoretical implications for patterns of testosterone secretion, mating systems, and breeding strategies. American Naturalist 136: 829-846.

WINGFIELD JC, J JACOBS \& N HILLGARTH (1997) Ecological constraints and the evolution of hormone-behavior interrelationships. Annals of the New York Academy of Science (USA) 807: 22-41.

WINGFIELD JC, DL MANEY, CW BREUNER, J JACOBS, S LYNN, M RAMENOFSKY \& RD RICHARDSON (1998) Ecological bases of hormone-behavior interactions: the "emergency life history state". American Zoologist 38: 191-206.

WINGFIELD JC \& RM SAPOLSKI (2003) Reproduction and resistance to stress: when and how. Journal of Neuroendocrinology 15: 711-724.

Associate Editor: Francisco Bozinovic

Received December 2, 2004; accepted March 1, 2005
WINGFIELD JC, CM VLECK \& MC MOORE (1992) Seasonal changes of the adrenocortical response to stress in birds of the sonoran desert. Journal of Experimental Zoology 264: 419-428.

WINGFIELD JC, CS WHALING \& P MARLER (1994) Communication in vertebrates aggression and reproduction: the role of hormones. In: Knobil E \& JD Neill (eds) The physiology of reproduction: 303342. Raven Press, Ltd., New York, New York, USA.

WOLFF JO (1994) Reproductive success of solitary and communally nesting white-footed mice and deer mice. Behavioral Ecology 5: 206-209.

YEH S, M-Y TSAI, Q XU, X-M MU, H LARDY, K-E HUANG, H LIN, S-D YEH, S ALTUWAIJRI, X ZHOU, L XING, BF BOYCE, M-C HUNG, S ZHANG, L GAN \& C CHANG (2002)

Generation and characterization of androgen receptor knockout (ARKO) mice: an in vivo model for the study of androgen functions in selective tissues. Proceedings of the National Academy of Sciences USA 99: 13498-13503.

ZAR JH (ed) (1996) Bioestatistical analysis. Third edition. Prentice-Hall, Upple Saddle River, New Jersey, USA. 663 pp.

ZIELINSKI WJ \& JG VANDENBERGH (1993) Testosterone and competitive ability in male house mice, Mus musculus: laboratory and field studies. Animal Behaviour 45: 873-891. 